\title{
WitTGENSTEIN Y LA RELIGIÓN ${ }^{11}$
}

Que esta última conferencia sobre la religión en el pensamiento de Ludwig Wittgenstein me haya tocado dictarla a mí tiene algo de paradójico. Porque de todos los colegas que me han precedido, soy yo tal vez el que menos familiaridad tenga con el pensamiento del filósofo austríaco, y a estas alturas del curso ustedes deben encontrarse ya muy familiarizados con su nada fácil manera de pensar.

Por otra parte, se nos ha recomendado elaborar una exposición de carácter introductorio sobre su pensamiento, lo cual espero cumplir a cabalidad. Pero se nos ha sugerido, también, que expusiéramos de manera libre, sin ceñirnos a un texto escrito; sugerencia que no voy a seguir, porque considero que todos ganamos si me someto a leer con cuidado las páginas que he escrito previamente, ya que de lo contrario corro el peligro de hablar mucho más y decir mucho menos en mi exposición.

En realidad, me he acercado con mayor atención últimamente al pensamiento de Wittgenstein, atraído por su forma peculiar y novedosa de plantear las cuestiones acerca de la religión, aunque ya algunas lecturas

11 Conferencia dictada en el curso organizado por el Departamento de Filosofía de la Universidad Nacional de Colombia en el primer semestre del año 2001, con motivo de los 50 años de la muerte del pensador austríaco. Las conferencias fueron publicadas en Botero (2001). 
anteriores habían despertado mi interés por sus planteamientos. Tuve un primer encuentro con su pensamiento en mis años de estudio en la Universidad de Lovaina, y volví a confrontarme con él cuando la Sociedad Colombiana de Filosofía llevó a cabo su IX Coloquio en el año 1989, cuyas ponencias fueron publicadas por la Universidad de Caldas bajo el título: Wittgenstein: Discusiones sobre el Lenguaje. Entre los varios textos que he tenido ocasión de leer luego con agrado, puedo citar el muy ponderado estudio escrito por Magdalena Holguín, Wittgenstein y el escepticismo, o los no menos interesantes de Raúl Meléndez, Verdad sin fundamentos: una indagación acerca del concepto de verdad a la luz de la filosofía de Wittgenstein, y de Jairo Iván Peña, Wittgenstein y la crítica a la racionalidad.

En cuanto a las ideas de este filósofo acerca de la religión, el interés provino de la innegable influencia que su pensamiento ha tenido en el surgimiento de toda una amplia gama de estudios acerca del lenguaje religioso, y también de la religión como creencia, provenientes de filósofos familiarizados con los problemas del lenguaje y que pertenecen a esa gran familia que ha sido llamada, de manera a mi parecer no muy precisa, "filosofía analítica". Estos escritores han retomado, en un ámbito por completo novedoso, temas que han sido objeto de frecuente discusión en la ya larga tradición del pensamiento cristiano, pero que la filosofía moderna, y sobre todo la contemporánea, había dejado de lado para que fueran tratados en forma casi exclusiva por los teólogos. En particular, la cuestión nada fácil acerca de las relaciones que puedan establecerse entre la fe religiosa y la razón.

En mirada panorámica y de forma muy esquemática, se pueden distinguir, por lo menos, cuatro grandes momentos en la historia de esta interminable discusión. En primer lugar, en los albores mismos de la historia del cristianismo, y también dentro del judaísmo en su encuentro con la filosofía griega, no faltaron quienes alertaron contra los peligros que significaba para la creencia religiosa el pretender apoyarse sobre la razón. Escritores como el apologeta Taciano (s. II d. C.) mostraron gran desconfianza frente a la sabiduría pagana, e insistían en que el cristianismo no buscaba el conocimiento, sino la salvación. Sin embargo, la corriente mayoritaria u ortodoxa buscó más bien una conciliación y un aprovechamiento de la sabiduría pagana para los fines de la evangelización. 
Será más tarde, en los siglos XII y XIII, al irrumpir en Europa el llamado Corpus aristotelicum, es decir, al ser conocida la obra completa de Aristóteles, cuando se lleve a cabo una nueva disputa de hondas repercusiones. Etienne Gilson, el conocido historiador del pensamiento medieval, no dudó en considerar esta conmoción intelectual como un fenómeno de al menos iguales proporciones y tan profundas consecuencias como el que tendrá lugar en el siglo XVI con la Reforma protestante y el Renacimiento. Señala cómo:

Exponer la historia de la filosofía del siglo XIII, época clásica de la filosofía medieval, equivale a definir las diversas actitudes que se adoptaron, en los diferentes medios filosóficos, frente al aristotelismo. En efecto, no solo centros de estudio como las Universidades de París y de Toulouse y Oxford, que acababan de ser creadas, sino también las grandes órdenes religiosas, como los dominicos y los franciscanos, han desempeñado un papel decisivo en la interpretación de la filosofía de Aristóteles (Gilson, 1976, p. 364).

Tomás de Aquino y Duns Escoto buscaron suavizar en lo posible las discrepancias entre la razón y la fe, llegando a sostener que entre ambas existe una especie de continuidad, a pesar de su radical diferencia. Por su parte, el nominalista franciscano Guillermo de Ockham se opondrá con firmeza a ese intento. Desde su perspectiva nominalista, no consideraba conveniente otorgarle a la razón demasiada confianza, y le parecía que permitirle que se inmiscuyera sin más en los asuntos religiosos podría conducir a graves estragos para la fe. Después de todo, como veremos que lo señala también Wittgenstein, la religión no es en lo primordial una doctrina o un conocimiento, sino una manera de actuar y de vivir.

Esta discusión volverá a presentarse, incluso con mayor beligerancia, cuando la Reforma protestante controvierta la interpretación que hacía la Iglesia de Roma de las Sagradas Escrituras, acusándola de haber convertido su enseñanza moral en argucias silogísticas. "En pocas palabras -dirá Lutero- todo Aristóteles es para la Teología como las tinieblas para la luz" (1883-2009, p. 226) ${ }^{12}$; y su compañero Philipp Melanchthon (1497-1560) buscará mostrar "cuán monstruosamente descarriados andan en cuestiones teológicas quienes han pretendido ofrecernos sutilezas aristotélicas, en lugar de la doctrina de Cristo" (1993, pp. 12-13). Juan Calvino, por su parte, muestra una clara desconfianza con respecto a las ideas filosóficas acerca 12 Doy la paginación de la edición de Weimar, indicada en la Bibliografía. 
de Dios (1968, I, pp. 5-6).

Finalmente, en la primera mitad del siglo XX, la teología protestante habrá de experimentar una nueva rebelión antirracionalista, iniciada en el siglo XIX por el filósofo danés Søren Kierkegaard (1813-1855) y liderada por la controvertida figura del teólogo suizo Karl Barth. Por la misma época en que Wittgenstein luchaba con sus ideas, se expandía por el ámbito de lengua alemana una corriente de pensamiento que arremetía contra la orientación que había tomado la teología protestante del siglo XIX bajo la orientación de Friedrich Schleiermacher (1768-1834). Como padre de la llamada "teología liberal", Schleiermacher había buscado adecuar la revelación cristiana a las condiciones del mundo moderno. Barth considera que en esa tarea de asimilación, respetable en muchos sentidos, la teología había llegado hasta poner en peligro, una vez más, lo específico del mensaje cristiano.

Cabe señalar cómo, en cada una de las sucesivas etapas de tan larga controversia, las posiciones obedecen a cuestiones muy conectadas con el momento histórico, y esto les confiere características peculiares que no son del caso analizar aquí. Lo que he querido resaltar es que la interpretación que nos ha ofrecido Wittgenstein de la religión, como un particular juego de lenguaje, se inserta, a mi parecer, muy bien dentro de esta ya larga controversia, lo que le ha permitido alcanzar resonancias que él mismo tal vez no se hubiera esperado. Es un hecho que sus opiniones sobre la religión no son en realidad muy numerosas, al menos en sus escritos propiamente filosóficos, y tampoco muy elaboradas. Pero la resonancia que ellas han tenido muestra que ha logrado movilizar resortes de pensamiento que se hallaban tensos, al abrirles nuevos horizontes para su ejercicio.

No sé hasta qué punto Wittgenstein haya podido estar influido por esas controversias, es decir, hasta qué punto las haya conocido. Lo que sí resulta claro para mí es que sus consideraciones acerca de la religión han ejercido una profunda influencia y han despertado una amplia e interesante discusión, precisamente porque vienen a insertarse de manera muy novedosa dentro de esa ya larga tradición.

Voy a organizar mi exposición sobre Wittgenstein en dos partes: en primer lugar, trataré de exponer sus ideas sobre la religión tal como aparecen en sus tres Lecciones sobre creencia religiosa, y luego examinaré la controversia entre dos buenos conocedores de su obra y de su persona, 
como son Norman Malcolm y Peter Winch. Esta controversia me parece que arroja mucha luz sobre el pensamiento religioso del pensador austríaco.

\section{Las tres lecciones sobre creencia religiosa}

Comencemos por recordar que el texto de estas Lecciones, dictadas en Cambridge en el verano de 1938, no es otra cosa que el resultado de unas notas tomadas por sus oyentes, y tomadas, por lo demás, de manera muy poco sistemática. Se trata en realidad de frases un tanto sueltas, cuyo significado a veces no resulta para nada claro. Sin embargo, es en ellas donde podemos leer de manera más directa lo que Wittgenstein pensaba sobre el fenómeno de la religión cuando se la considera como un juego de lenguaje. Este concepto central en el pensamiento del llamado segundo Wittgenstein, que ustedes ya han tenido ocasión de conocer a lo largo de este curso, nos lo explica muy bien Juan José Botero, en un estudio que hizo sobre el mismo, con las siguientes palabras: "Yo me atrevería a identificarlo -nos dice- con lo que Wittgenstein llama una 'forma de vida', es decir, un conjunto de actividades humanas gobernadas por reglas que especifican ciertas condiciones para el uso del lenguaje" (AA. VV., 1991, p. 86).

\section{a. Primera lección}

En la primera lección, Wittgenstein señala cinco características de las creencias religiosas que, a su parecer, determinan la peculiaridad de las mismas.

1. La primera atañe al contenido de las creencias y su relación con la fe del creyente. Para ello, examina cuál sería propiamente la diferencia que podría establecerse entre un creyente y un no creyente, y pone como ejemplo el carácter peculiar que tendría una controversia entre ellos.

Wittgenstein afirma:

Estas controversias parecen completamente diferentes de cualquier controversia normal. Las razones parecen enteramente diferentes de las razones normales. En cierto sentido, ellas no son nada concluyentes. La gracia está en que, si hubiera pruebas, se destruiría de hecho todo el asunto. Cualquier cosa que normalmente llamo prueba no me influiría lo más mínimo. (1996, p. 132). 
Esto me hace recordar la famosa controversia que llevaron a cabo, en un programa de la BBC de Londres, el jesuita Frederick C. Copleston y el pensador Bertrand Russell, en el año 1948, y cuyo final muestra claramente que hablaban lenguajes que podríamos considerar casi inconmensurables ${ }^{13}$. "La doctrina de la inconmensurabilidad -nos explica Hilary Putnamconsiste precisamente en que dos personas que hablan no pueden entenderse porque sus palabras tienen 'significados' diferentes" (p. 153). Sin embargo, Wittgenstein no dice propiamente que ambos lenguajes, el del creyente y el del no creyente, sean en realidad inconmensurables. Porque el hecho de que no puedan entenderse entre ellos no se resuelve preguntando si ambos quieren decir lo mismo cuando usan términos iguales. De ahí que nos diga: "Podría ser que la diferencia no se mostrara por ninguna explicación del significado" (1996, p. 130). Y que más adelante señale:

Si el señor Lewy es religioso y dice que cree en el Día del Juicio, yo no sabría siquiera decir si le entiendo o no. He leído las mismas cosas que él. En un sentido más importante sí sé lo que quiere decir. Si un ateo dice "no habrá juicio final" y otra persona dice que lo habrá, ¿quieren decir lo mismo? No está claro cuál es el criterio para saber si quieren decir lo mismo. Podrían describir las mismas cosas. Ustedes podrían decir que esto muestra ya que quieren decir lo mismo. (1996, p. 135).

Así pues, la controversia entre un creyente y un no creyente no es, para Wittgenstein, ante todo un asunto que tenga que ver con los contenidos fácticos de sus respectivas afirmaciones o negaciones. No se trata, o al menos no se trata en primer término, de que el creyente acepte ciertos hechos o acontecimientos que un no creyente rechace. De modo que la cuestión importante no consiste en estar convencido de que en cierto momento y en cierto lugar vayan a tener lugar ciertos y determinados acontecimientos. Porque el solo hecho de que alguien esté convencido de que tal cosa va a suceder no lo convierte sin más en un verdadero creyente religioso. Creer en el Juicio Final, en el sentido religioso del término, significa más bien orientar su vida a la luz de esa imagen, sin importar el carácter específico de la misma. Afirma Wittgenstein: 
Supongan que adopta esta regla para su vida: creer en el Juicio Final. Haga lo que haga siempre lo tiene en mente. ¿Cómo sabemos si podemos decir que cree que sucederá, o que no lo cree? Preguntárselo no es suficiente. Probablemente dirá que tiene pruebas. Pero lo que tiene es lo que podríamos llamar una creencia inconmovible. Ello se mostrará, no mediante razonamientos o apelando a razones ordinarias para creer, sino más bien regulando todo en su vida. (1996, p. 130).

Creer no es entonces - $\mathrm{O}$ al menos no lo es en primera instancia- un asunto de conocimiento, de saber o pretender saber algo que quien no cree no sabe o no puede saber, sino de vivir de acuerdo con ciertas convicciones. Como ya lo decía el Evangelio: "Por sus frutos los conoceréis" (Mt., 7: 16).

En el Diario, escrito en el año 1937, encontramos una reflexión que subraya aún más esta manera de entender la religión:

Una cuestión religiosa es solo una cuestión de la vida, o es palabrería (vacía). Este juego de lenguaje -se podría decir- solo se juega con cuestiones de la vida. Del mismo modo que la palabra 'iay!' no tiene significado -sino como grito de dolor. (2000, p. 203; 23-II-1937) ${ }^{14}$.

La frase final de esta cita daría pie para pensar que la intención de Wittgenstein es la de mostrar que el lenguaje religioso es no cognitivo, no descriptivo, sino que solo expresa en realidad sentimientos o actitudes del creyente. Sin embargo, como tendremos ocasión de verlo, Wittgenstein en las Lecciones se cuida de no llegar tan lejos. Si observamos con atención la manera como los creyentes expresan sus convicciones, podremos ver que, en alguna forma, pretenden comunicar conocimientos o al menos algo semejante a ellos.

2. Ahora bien, si la importancia del lenguaje religioso no está en los contenidos de sus enunciados, el sentido de una creencia religiosa hay que buscarlo más bien en su capacidad para orientar el comportamiento, es decir, en que la persona creyente actúe en forma muy diferente a como lo haría si no fuera creyente. Más que una cuestión de contenidos, se trata de una cuestión de forma. De ahí que la diferencia no se sitúe en el contenido mismo de las acciones que uno u otro llevan o pueden llevar a cabo, sino en el sentido bajo cuya orientación las realizan. Recordemos lo dicho anteriormente:

14 Para las citas de este Diario daremos la paginación original que se halla en la versión española y la fecha del texto. 
Si el señor Levy es religioso -dice refiriéndose a uno de sus alumnos presentes-, y dice que cree en el Día del Juicio, yo no sabría siquiera decir si le entiendo o no. He leído las mismas cosas que él. En un sentido más importante sí sé lo que quiere decir. (1996, p. 135)

La frase final es muy significativa, porque corrige en cierta forma lo señalado antes. No se trata de que haya una total incomprensión entre el creyente y el no creyente, ya que este último puede entender al creyente "en un sentido muy importante". Pero para ello no se debe atender a los contenidos de tales creencias, sino a la forma como esos contenidos se proyectan sobre el comportamiento del creyente. Porque Wittgenstein considera que el carácter religioso de la creencia no descansa en esos contenidos descriptivos con los cuales la fe se manifiesta, sino en la repercusión que los mismos tengan sobre la conducta. Si bien es cierto que no resulta fácil saber si entendemos o no al creyente, en un sentido más profundo, es decir, en el sentido en que esa creencia orienta su comportamiento, sí podemos saber lo que él quiere decir.

3. De ahí que, en tercer lugar, la diferencia entre un creyente y un no creyente, al no situarse propiamente en los objetos de la creencia, no permita establecer por sí misma una mayor o menor cercanía entre ellos. En otras palabras, al tratarse de algo que corresponde a la forma y tiene por ello carácter cualitativo, no cabe predicarle un más o un menos. A propósito de esto, asegura Wittgenstein:

Supongan que alguien fuera creyente y dijera: "Creo en el Juicio Final", y que yo dijera: "Bueno, no estoy tan seguro. Quizás". Ustedes dirían que hay un enorme abismo entre nosotros. Si él dijera: "Hay un avión alemán ahí arriba", y yo dijera: "Quizás. No estoy tan seguro", ustedes dirían que estamos bastante cerca. No es una cuestión de que estemos cerca o no de alguna parte, sino de que su propio planteamiento se realiza en un plano por completo diferente, cosa que podrían expresar diciendo: "Usted piensa algo enteramente diferente, Wittgenstein". (1996, p. 129).

Esto significa que la diferencia entre el creyente y el no creyente no puede medirse de manera cuantitativa como una mayor o menor aproximación a un cierto estado de cosas, sino que se trata de una diferencia claramente cualitativa que establece una heterogeneidad entre la persona que cree y la que no cree. Porque la fe es considerada por Wittgenstein sobre todo como 
un acto de confianza, y quien duda es porque ha comenzado a perder la confianza. Sin embargo, no cabría decir que quien duda de su fe ya por ello la haya perdido.

Wittgenstein parece insistir en la visión, de origen protestante, de la fe en su carácter 'fiducial', es decir, que pone el acento no tanto en los contenidos doctrinales de la creencia (fe doctrinal), cuanto en el acto de confiar en una palabra y en la persona que la ha pronunciado. Pero con ello, como bien se sabe, se corre el peligro de vaciar la creencia de todo contenido y de convertirla en un acto ciego de voluntad cercano al fanatismo.

Ahora bien, en la conferencia, Wittgenstein no se cansará de insistir en que la creencia no es propiamente un asunto de conocimiento de objetos, y que el lenguaje religioso, por lo tanto, no cumple, al menos no primordialmente, una función descriptiva, sino que se refiere a la manera como el creyente asume su forma de vivir. No se trata, por lo tanto, de poseer conocimientos que un no creyente no posea, de tener acceso a objetos que le están vedados al incrédulo, sino de que las convicciones acerca del sentido de su existencia sean diametralmente diferentes en un caso y en el otro. De ahí que quien, frente a una afirmación como la del Juicio Final, dijera que no está seguro de ello, no se halla más o menos cercano de la posición del creyente, sino que entre ellos se abre un completo abismo, porque en realidad juegan juegos de lenguaje diferentes, ya que, para decirlo en palabras de Juan José Botero, en el conjunto de sus actividades humanas, las reglas que especifican las condiciones para el uso del lenguaje son muy diferentes.

A este propósito, Wittgenstein trae unos ejemplos que resultan muy esclarecedores:

Supongan que hay dos personas y una de ellas, a la hora de decidir qué rumbo tomar, piensa en términos de retribución, mientras que la otra no lo hace. Una, por ejemplo, puede inclinarse a interpretar todo lo que le sucede como una recompensa o como un castigo, mientras que la otra no piensa en eso para nada. Si está enferma, puede decir: “¿Qué he hecho yo para merecer esto?". Esta es una manera de pensar en términos de retribución. Otra manera es pensar, en general, siempre que uno se avergüenza de sí mismo: "Esto será castigado". Consideren dos personas, una de las cuales habla de su conducta y de lo que le sucede en términos de retribución, mientras que la otra no lo hace. Esas personas piensan de 
modo completamente diferente. Sin embargo, no por eso pueden ustedes decir que ellas creen cosas diferentes. (1996, p. 131)

Ahora bien, el ejemplo señalado por Wittgenstein debe entenderse de manera correcta. Porque, como bien lo hace notar Hilary Putnam, sería un grave error considerar que la primera persona, aquella que piensa su vida en términos de retribución, esté presentada aquí como un modelo de creyente religioso. Esto sería reducir la religión a su forma más precaria, y solo cabría aplicarlo a ciertas formas muy simples de religiosidad en las que se busca únicamente alcanzar beneficios o evitar castigos. Por eso aclara Putnam:

El ejemplo no depende de que lo sea o no [creyente]. Lo que Wittgenstein quiere señalar con ese ejemplo es que la propia vida puede organizarse bajo muy diferentes imágenes. $\mathrm{Y}$ se propone indicar que la religión tiene más que ver con la clase de imagen a la que uno le permite que organice su vida, que con las formas de expresar esa creencia. (1996, p. 146)

Por eso, para entender correctamente la idea de Wittgenstein, es importante tener muy en cuenta esta observación, ya que no se trata de reducir la creencia religiosa a una actitud interesada de premios y castigos, como si el verdadero creyente fuera aquel que no obra mal por temor al castigo o que solo obra bien por el interés en el premio. La intención del pensador austríaco es recalcar lo que ha venido diciendo, a saber, que el juego de lenguaje religioso está orientado al comportamiento y busca incidir en la manera de vivir del creyente, más que ilustrarlo con doctrinas de carácter teórico. Podría decirse, entonces, que se trata más de unas reglas de juego que de una doctrina teórica:

Una vida diferente -escribe en el Diario el 4 de febrero de 1937- pone en primer plano imágenes por completo diferentes. Como la necesidad enseña a rezar. Esto no significa que por esa vida diferente uno cambie necesariamente sus opiniones. Pero, si se vive de otro modo, entonces se habla de otro modo. Con una nueva vida se aprenden nuevos juegos de lenguaje. (2001, p. 161).

El lenguaje religioso es, entonces, la manifestación de un cierto modo de vida, es la expresión de una manera diferente de comprender la propia existencia, la cual se orienta gracias a las imágenes bajo las cuales se organiza. 
4. Una cuarta característica de la creencia religiosa es que en ella las razones no juegan, no suelen jugar y tal vez no deban jugar un papel decisorio. Wittgenstein señala, a este propósito, el carácter tan débil de las razones que suelen darse para apuntalar una creencia religiosa.

El Padre O'Hara es una de esas personas que hacen de esto una cuestión científica. Aquí hay gentes que tratan esas pruebas de modo diferente. Ellos basan las cosas en pruebas que, tomadas en cierto sentido, parecerían sumamente débiles. Basan cosas enormes en estas pruebas. ¿Diré que son irracionales? No quiero decir de ellos que sean irracionales. Yo diría, y esto es obvio, que ciertamente no son racionales. 'Irracional' implica para cualquiera un reproche. Quiero decir: ellos no tratan esto como una cuestión de racionalidad. Cualquiera que lea las Epístolas [de San Pablo] lo encontrará expresado allí: no solo que no sea racional, sino que es una locura. No solo no es racional, sino que no pretende serlo. Lo que me parece ridículo en el caso O’Hara es que lo haga aparecer como racional (1996, pp. 134-135).

Se trata aquí de un asunto que, como vimos, ha sido objeto de interminables discusiones en el seno de la teología cristiana, discusiones que llegan hasta nuestros días. ¿Qué papel desempeña la razón en la creencia? A esta pregunta han respondido, como ya lo indicamos, desde la doctrina tomista más ortodoxa dentro del catolicismo romano, hasta el irracionalismo huraño de Kierkegaard. Mientras que el primero sostiene que el ejercicio correcto de nuestra razón puede situarnos en los umbrales mismos de la fe religiosa, el existencialismo kierkegaardiano considera la razón como su peor amenaza, al entender la fe precisamente como el rechazo a la racionalidad en cuanto criterio de conducta: credo quia absurdum (creo porque es absurdo), dice Kierkegaard, repitiendo palabras que se le han atribuido al apologista cristiano y Padre de la Iglesia Tertuliano (entre los años 160 y 220), aunque tal atribución resulta dudosa.

En la tradición cristiana, esta cuestión hunde sus raíces en la doctrina de San Pablo, a la que hace alusión Wittgenstein. El Apóstol dio a conocer en repetidas ocasiones, en sus epístolas, su desconfianza frente a la sabiduría de los paganos, es decir, frente a la tradición filosófica griega en la que había sido formado. El texto clásico lo constituye su primera Carta 
a los cristianos de la comunidad griega de Corinto, puerto situado en el corazón mismo de Grecia:

La palabra de la cruz es locura para los que se pierden, pero es poder de Dios para los que nos vamos a salvar. Porque está escrito: 'Destruiré la sabiduría de los sabios, y desharé la inteligencia de los inteligentes. ¿Dónde está el sabio?, ¿dónde el investigador de este mundo?, ¿no ha hecho Dios enloquecer la sabiduría del mundo? [...] Porque lo que es tontería en Dios, es más sabio que los hombres, y lo que es debilidad en Dios, es más fuerte que los hombres (1 Cor., 1: 19-25).

A Wittgenstein le interesa subrayar cómo, en el juego de lenguaje religioso, los argumentos racionales no desempeñan papel alguno, o al menos su papel resulta, por completo, secundario. De ahí que los intentos del Padre O’Hara, en su contribución a un Simposio sobre Ciencia y Religión que tuvo lugar en Londres en 1932, le resulten por completo ridículos. Considerar a la religión como un asunto científico significa, para Wittgenstein, desconocer por completo su verdadero sentido y verse enredado así en falsos problemas, cuya búsqueda de solución no solamente conduce al ridículo, sino que convierte la religión en una verdadera superstición. A este propósito nos dice H. Putnam:

Wittgenstein está interesado en negar cualquier continuidad entre lo que él considera creencia religiosa y creencia científica. Cuando hay continuidad, y solo cuando la hay, Wittgenstein se halla dispuesto a utilizar palabras como 'ridículo', 'absurdo', 'crédulo', 'superstición'. (1996, p. 150).

Por eso dice Wittgenstein: "Decididamente yo llamaría irracional a O’Hara. Diría: si esto es creencia religiosa, entonces es pura superstición toda ella" (1996, p. 136).

En realidad, el asunto es un poco más complejo. Porque en la tradición teológica cristiana se ha establecido una clara diferencia entre la cuestión acerca de la existencia de Dios y las otras verdades de la fe. Estas últimas son consideradas como verdaderos misterios que los seres humanos solo podemos llegar a conocer por medio de la revelación. La existencia de Dios, en cambio, es considerada por muchos teólogos como una verdad 
que la razón humana puede alcanzar por sus propios medios, y así lo ha sostenido con toda claridad la autoridad eclesiástica católico-romana.

Ahora bien, la doctrina de San Pablo con respecto a la sabiduría pagana hizo que los teólogos cristianos compartieran una gran desconfianza con respecto al papel de la razón en el proceso de la fe religiosa. Todos se empeñarán, de formas muy diversas, en trazar límites claros entre lo que llamaron conocimiento por la razón natural y aquello que constituye un acto genuino de fe religiosa. Sin embargo, cuando en el siglo XIII irrumpa el aristotelismo produciendo todo el desconcierto del que ya hicimos mención, Tomás de Aquino asumirá la gigantesca tarea de hacer compatible esa filosofía, que había llegado a ser tenida por muchos como la expresión misma de la verdad racional, con las doctrinas del cristianismo. En esta forma tomará partido en esa vieja disputa acerca de la relación que debería establecerse entre la razón y la fe, entre la labor que habían llevado a cabo los pensadores del paganismo y la que debían asumir ahora los pensadores cristianos. Después de todo, unos y otros se proponían ofrecer a los hombres orientaciones acerca de la manera como debían entender y conducir sus existencias.

El dominico Tomás de Aquino y el franciscano Duns Escoto, entre muchos otros, tomarán partido en defensa de una continuidad en las tareas. Para ellos, la revelación cristiana había venido a perfeccionar con nuevas verdades, inaccesibles para nuestra razón humana, la tarea emprendida por aquellos filósofos antiguos. Mientras que el franciscano Guillermo de Ockham, retomando y perfeccionando la doctrina de los nominalistas del siglo XII, defenderá lo que Alfred Freddoso ha llamado con mucha propiedad un "separatismo irénico" (Spade, 1999, p. 346), es decir, separar para resolver el conflicto. Ockham busca establecer una clara línea divisoria entre la razón y la fe, evitando, sin embargo, confrontarlas como enemigas. Será esta corriente de pensamiento, a través de la llamada "vía nueva", la que ejercerá una gran influencia en Martín Lutero y en los demás reformadores.

El interés claro de Wittgenstein es sacar a la luz la innegable diferencia que existe entre el lenguaje de la religión y el lenguaje del conocimiento o de la ciencia. El juego de lenguaje religioso está, por muchos aspectos, más cerca del juego de lenguaje del amor que del lenguaje del conocimiento. 
En esto retoma sin duda un punto de vista que había sido sustentado por la corriente franciscana, con su clara inclinación por el voluntarismo, es decir, por aquella doctrina que le otorga una superioridad a la voluntad sobre el entendimiento, y que tiene sus raíces en Agustín de Hipona. Sin embargo, el representante más significativo de esta manera de entender el lenguaje religioso es, sin duda, San Buenaventura.

\section{El 19 de abril de 1937 escribe Wittgenstein en su Diario:}

Creo: por la palabra 'creer' se ha causado en la religión mucho daño, un daño terrible. Todas esas enrevesadas ideas sobre la "paradoja", el significado eterno de un hecho histórico, y semejantes. Pero si en lugar de "Fe en Cristo" dices: "Amor a Cristo", desaparece la paradoja, es decir, esa provocación del entendimiento. ¿Qué tiene que ver la religión con un cosquilleo así del entendimiento? (También esto puede pertenecer a su religión para alguien). No es que entonces pudiera decirse: Bueno, ahora todo es sencillo -o comprensible. No es en absoluto comprensible, solo es no incomprensible. (2000, pp. 238-239).

La intención parece clara. Se trata de dejar a un lado las controversias sobre la racionalidad o irracionalidad de las creencias religiosas, para centrar la atención en su núcleo de sentido. Y este núcleo, en el caso del cristianismo, se halla en la persona de Jesús de Nazaret. Por eso, amarlo, es decir, conocerlo, apreciar su comportamiento y sus enseñanzas, y tratar de comportarse de acuerdo con ellas, en eso consiste realmente la religiosidad. Más allá o más acá de las controversias doctrinales, lo central es la figura de Cristo y su seguimiento.

5. Hay, por último, una característica de la creencia religiosa que a Wittgenstein le llamaba mucho la atención, y que ejerció sobre él, como lo sabemos por sus diarios y otros escritos, un atractivo muy especial, a saber, el carácter radical de la convicción que la acompaña. A propósito de esto, asegura:

La creencia es un hecho mucho más fuerte: renunciar a placeres, apelar siempre a esa imagen. En un sentido, hay que llamar a esto la más firme de todas las creencias, porque la persona arriesga por ello lo que no arriesgaría por cosas mucho mejor fundadas para ella. Aunque distinga entre cosas bien fundadas y no bien fundadas. (1996, p. 130). 
Con ello trae a colación lo que, como ya hemos visto, se conoce en la tradición teológica cristiana con el nombre de fe fiducial, cuestión ligada estrechamente con la anterior, es decir, con la relación entre la fe y la razón. En esto ha insistido sobre todo la doctrina protestante, apoyada en sus orígenes nominalistas de corte agustiniano, que le otorga una preeminencia a la voluntad sobre el conocimiento. Frente a una fe llamada dogmática, de rasgos racionalistas, que pone el acento en la aceptación intelectual del contenido de los dogmas religiosos y en la corrección doctrinal, tal como la que predomina en la tradición oficial de la Iglesia Católica, los protestantes han insistido en que la creencia religiosa es, ante todo, un acto de la voluntad. Se trata de un acto por el cual se cifra la confianza sobre una palabra dada, sobre una promesa de salvación; acto que, además, como insistirá sobre todo el calvinismo, es él mismo un don de Dios, una gracia que se recibe sin merecimiento alguno.

Creer es entonces confiar en alguien, y de ahíla firmeza de esa convicción, a pesar de, o tal vez precisamente por la falta de razones constringentes, ya que se trata precisamente de un acto de confianza. El término 'confianza', cuando se refiere a una persona o a la palabra que alguien nos ha dado, implica cierto grado de certidumbre, pero una certidumbre que no excluye la posibilidad del error. Precisamente porque la duda no puede ser excluida, es que hablamos de confianza, y no de una simple convicción racional. Sin embargo, al tratarse de un compromiso personal con la palabra dada, las consecuencias de esa confianza pueden llegar a ser más significativas que las que pudieran seguirse de una simple convicción intelectual. En otras palabras, un acto de confianza descarta la posibilidad de alcanzar una certeza absoluta sobre la persona o sobre la palabra dada por dicha persona; porque si se diera esa certeza absoluta, la confianza desaparecería; tendríamos un conocimiento seguro, pero no confianza. Ahora bien, esa falta de certeza conceptual se ve no solo compensada, sino superada por la voluntad de confiar, por la decisión de entregarse, así como por el objeto de dicha confianza que no es otro que la palabra de Dios. De ahí la gran fuerza que tiene el acto de fe; fuerza que a Wittgenstein le llama tanto la atención.

La conclusión de esta Primera lección podemos muy bien resumirla con las palabras de Hilary Putnam: "Dicho brevemente -y tal vez ésta sea la única cosa absolutamente clara con respecto a las lecciones-, Wittgenstein cree que la persona religiosa y el ateo hablan sin comprenderse" (1996, p. 143). 


\section{b. Segunda lección}

El asunto alrededor del cual gira la segunda lección es el de los enunciados teológicos. En último término, los enunciados teológicos vienen a ser aseveraciones sobre Dios. Se dice que Dios es esto o es aquello, o que hace esto o hace aquello. Conviene tener en cuenta que cuando hablamos del lenguaje religioso estamos refiriéndonos en realidad a dos lenguajes o a dos juegos de lenguaje al menos parcialmente diferentes. Por una parte, al lenguaje mediante el cual los creyentes expresan sus creencias, como cuando recitan el credo o su profesión de fe, cuando celebran sus ritos o ceremonias, entonan sus cantos o leen la Escritura Sagrada. Por otra parte, al lenguaje de los teólogos, con el cual expresan sus reflexiones acerca de ese primer lenguaje propiamente religioso. Se trataría entonces, en este segundo caso, de un verdadero metalenguaje, cuyo estatuto, así como sus relaciones con el primero, no son para nada fáciles de establecer, y han dado pie a una muy variada multiplicidad de propuestas de explicación.

Sin embargo, Wittgenstein no tiene en cuenta estas complejas distinciones, y se refiere en general al lenguaje religioso como aquel que está condicionado por las reglas que se establecen a partir de ese modo de vida o juego de lenguaje que llamamos creencia religiosa. La segunda lección, a pesar de hablar sobre el lenguaje religioso, no establece una clara diferenciación entre religión y teología o, para ser más precisos, entre el lenguaje o los lenguajes de la religión y el lenguaje o los lenguajes de la teología. Uno bien podría decir que a Wittgenstein no parece interesarle la teología.

Por otra parte, conviene también señalar que, cuando Wittgenstein se refiere a la religión como un juego de lenguaje, está pensando, sobre todo, en su propia tradición religiosa. Educado en el seno de una familia católica, con raíces hebreas, no solo tuvo ocasión de conocer el ambiente protestante, sino que mostró un gran interés por los escritos de Kierkegaard, cuyo talante marcadamente antirracional estaba ejerciendo, como ya hemos visto, una significativa influencia en la teología protestante de los comienzos del siglo XX.

El problema con la palabra 'Dios' señala la segunda lección, es que su aprendizaje tiene semejanzas con el aprendizaje de otros términos que designan personas, y más precisamente, personas ausentes, como podrían ser unas tías de la familia de las que se tienen unas fotografías o unos recuerdos anecdóticos. El lenguaje religioso sobre Dios suele insistir en 
su trascendencia, de modo que todo lo que podamos decir de él tiene un carácter figurativo. Dice Wittgenstein:

La palabra 'Dios' está entre las primeras que se aprenden: imágenes y catecismos, etc. Pero sin las consecuencias de las imágenes de las tías de la familia, por ejemplo. No se me ha mostrado [lo que la imagen simboliza]. La palabra es usada como una palabra que representa a una persona. Dios ve, recompensa, etc. "Una vez mostradas todas esas cosas, ¿ he comprendido lo que esa palabra significa?". Yo diría: "Sí y no"” He aprendido lo que no significa. (1996, p. 136).

La reflexión apunta aquí a un aspecto particularmente significativo de la tradición tanto religiosa como teológica, a saber, la llamada "teología negativa". Dada la trascendencia de Dios, todo lo que podemos decir de él debe ser claramente diferenciado de lo que podemos decir de las cosas que conocemos. Pero como nuestro lenguaje se elabora para referirse a esas cosas que están a nuestro alcance, la manera más adecuada para referirse a Dios viene a ser por la vía de la negación. Sabemos lo que Dios no es, pero no podemos saber con plena claridad lo que Él sea, a no ser en la medida en que Él mismo se nos revele.

En la teología cristiana, el punto de referencia inicial de esta corriente se encuentra en el texto Los nombres divinos, del llamado Pseudo Dionisio o Dionisio el Areopagita, escrito que gozó de una gran autoridad a todo lo largo de la Edad Media y que marca profundamente la mística cristiana. El nombre del autor aludía al discípulo que siguió a Pablo luego de su famoso discurso en el Areópago de Atenas (cf. Hch, 17: 34), y durante mucho tiempo se creyó que sus escritos contenían la doctrina esotérica del apóstol. Con un acento marcadamente neoplatónico, insiste una y otra vez en que de Dios, quien se halla más allá de todo ser y de todo ente, solo cabe hablar apoyados en los textos sagrados mediante los cuales Él mismo se nos ha revelado:

Así pues, no hay que osar por entero decir, ni tampoco reflexionar algo acerca de la divinidad supraesencial y oculta, más allá de lo manifestado a nosotros por la vía divina a partir de los Sagrados Oráculos [las Sagradas Escrituras]. Pues sería desconocimiento de su supra-esencialidad por encima de la razón, inteligencia y esencia. Para ella hay que aplicar la ciencia supra-esencial, alzándonos sobre lo escarpado tanto como el rayo de los 
Oráculos teárquicos nos lo conceda, dirigiéndonos hacia los esplendores superiores con la prudencia y sacralidad que rodea lo divino (Dionisio, 2005, p. 207).

Ahora bien, esta influencia dionisiana ha sido señalada y analizada muy bien en la misma teología de Tomás de Aquino, por el filósofo y teólogo Jean-Luc Marion en su ensayo "Santo Tomás de Aquino y la onto-teo-logía", que forma parte de su libro Dios sin el ser. Luego de examinar los diversos elementos que constituyen la onto-teo-logía, tal como ésta ha sido definida por Heidegger, y mostrar cómo ninguno de ellos puede aplicarse en forma adecuada al pensamiento de Tomás, nos dice:

Evidentemente, resulta indiscutible que Tomás de Aquino designó a Dios como esse. Pero resulta discutible que, asignado como propio de Dios, este esse designe lo que la metafísica, incluida "la pregunta por el ser", ha llegado a concebir -y no un más allá del ser mismo, sea cual sea. Esta transgresión no implicaría ninguna pérdida óntica u ontológica, ni ninguna irracionalidad: solo constata que, racionalmente, solo conviene a Dios lo que se conforma al infinito. (2005, p. 309).

Por otra parte, cuando prestamos atención a la cuestión sobre la existencia del objeto mencionado con la palabra 'Dios', vemos, dice Wittgenstein, que "la cuestión de la existencia de un dios o de Dios desempeña un papel por completo diferente del de la existencia de cualquier persona u objeto de los que haya oído hablar alguna vez" (1996, p. 136).

En un artículo de 1958, titulado La posibilidad de los enunciados teológicos, Ian M. Crombie elaboró un estudio, detallado y cuidadoso, acerca de las por él llamadas "anomalías del lenguaje religioso", señalando que existen dos clases de tales anomalías. Unas que corresponden al sujeto de las oraciones, es decir, al uso de la palabra 'Dios', y otras al predicado, es decir, a lo que suelen decir los creyentes a propósito de Dios. En cuanto a la primera, que es aquella a la que se refiere aquí la cita de Wittgenstein, nos dice Crombie:

La noción de Dios como espíritu es en verdad un error categorial, o una transgresión categorial, pero cometida en forma deliberada para expresar lo que sentimos previamente $y$, si sentimos algo previamente, cometemos de manera deliberada la transgresión categorial para expresar que ese 
sentimiento tiene algún significado -a saber, aquel que está designado para expresar (citado en Romerales, 1992, p. 93).

La función peculiar que juega el sujeto 'Dios' en los enunciados teológicos muestra que se refiere a un cuasisujeto, a una entidad sui géneris, que si bien es tratada como si fuera un objeto real y determinable, en realidad no es tal. Dicho en otras palabras, el lenguaje religioso no transmite, o no parece transmitir, un conocimiento acerca de un objeto determinado, ya que de ese mismo objeto se dice que rebasa todo conocimiento. No se trata propiamente de ofrecernos un conocimiento que pudiéramos alcanzar por medio de una revelación, sino de expresar un sentimiento de limitación y un anhelo de transgredir esos límites.

Esto, por supuesto, pareciera poner en entredicho casi toda la teología cristiana, ya que la misma ha operado siempre, o casi siempre, bajo el supuesto de que la revelación cristiana le ha dado la oportunidad al hombre de acceder a conocimientos que están más allá de la capacidad natural de su razón. Sin embargo, a todo lo largo de la historia del pensamiento cristiano, ya desde sus orígenes y bajo la influencia de la gnosis, o luchando contra la misma, se ha ido conservando, como lo he señalado, una corriente muy fuerte de "teología negativa”. El sentido del término 'Dios' es el de lo indecible, de aquello que supera todas las posibilidades tanto del lenguaje como del pensamiento humano. Forma de pensar que ha sido compartida por casi todos los grandes místicos cristianos. Sin embargo, el interés de Wittgenstein parece centrarse, sobre todo, en el sentido operativo que ese término tiene dentro del juego de lenguaje religioso. Resalta para ello dos aspectos de su particular interés.

Por una parte, que "el no creer en la existencia de Dios ha sido considerado algo malo. Normalmente, si no creo en la existencia de alguna cosa, nadie pensaría que hay algo incorrecto en ello" (1996, p. 137). Lo cual no hace sino resaltar el carácter moral de tal creencia, es decir, que se trata, en primer término, de ofrecerle al comportamiento una cierta manera de comprenderse, una cierta perspectiva para interpretarse, una actitud básica desde la cual responder a las cuestiones que la vida le plantea.

Ahora bien, además de ese sentido moral que se le atribuye a la creencia en Dios o a su negación, hay otro aspecto que llama la atención del pensador austríaco, esta vez con respecto a la idea de creer: 
Además, existe este extraordinario uso de la palabra 'creer'. Se habla de creer y al mismo tiempo no se usa 'creer' como se hace ordinariamente. Podrían decir (en el uso normal): "Usted solo cree - jah, bueno!.... Aquí se usa de modo por completo diferente; por otra parte, no se usa como generalmente usamos la palabra 'conocer'. (1996, p. 137).

El uso normal de la palabra 'creer' parece ser aquel en el que se dice que creemos en algo porque no tenemos razones suficientes para sustentar nuestra creencia y convertirla en conocimiento. "Creemos que mañana va a llover", precisamente porque no sabemos si ello sucederá de hecho. Si alguien solo cree en algo, significa que está convencido de ello sin razones suficientes como para poder demostrarlo y en esto se parece a la creencia religiosa. Es el caso, por ejemplo, cuando alguien afirma que cree saber quién ha sido el ladrón, pero no está en condiciones de poderlo demostrar. Ahora bien, si en el caso ordinario la creencia implica un grado inferior de certeza o de seguridad que cuando decimos conocer algo, en la creencia religiosa parece ocurrir todo lo contrario. Esa misma falta de razones parece otorgarle una seguridad que supera por completo la que puede alcanzarse en el conocimiento por meras razones, ya que, como lo pudimos notar anteriormente, se apoya en una decisión de la voluntad que apunta a confiar en la palabra misma de Dios y apunta a la manera de comportarse.

Creencia religiosa no es, entonces, ni una simple creencia por falta de razones suficientes, ni un saber apoyado en razones valederas. Una vez más, se trata de un acto de la voluntad que brota de una actitud muy particular con respecto a la propia existencia. Y es este carácter particular el que Wittgenstein se ha propuesto resaltar.

Lo que el texto de esta segunda lección dice a continuación me resulta bastante confuso. Las notas tomadas no permiten seguir con claridad el hilo de la argumentación. Ensaya diversos ejemplos que parecen apuntar en sentidos divergentes. Se nota muy bien que no se trata de una transcripción de la lección, sino de notas tomadas un poco al desgaire. Lo que logro entender es que Wittgenstein se propone señalar cómo un creyente no apoya en realidad su convicción sobre las razones que podría tener para ello, ni tampoco sobre la posibilidad de señalar el objeto de la misma, porque sabe muy bien que tal objeto no puede ser representado de manera directa. 
Trae entonces a colación el famoso cuadro pintado por Miguel Ángel en la Capilla Sixtina, para decirnos:

Tomen La creación de Adán. Pinturas de Miguel Ángel que representan la creación del mundo. No hay nada, en general, como una imagen para explicar los significados de las palabras, y considero que Miguel Ángel era tan bueno como el que más e hizo todo lo que pudo, y allí está la pintura de la Divinidad creando a Adán. Si alguna vez la viéramos, seguro que no pensaríamos que eso es la Divinidad. La imagen tiene que ser usada de un modo por completo diferente si vamos a llamar 'Dios' a ese hombre con la extraña capa, etc. (1996, pp. 140-141).

Cabría pensar que con este ejemplo Wittgenstein se propone mostrar cómo el lenguaje religioso se aparta por completo de cualquier intento descriptivo. El uso tan peculiar que hace de las imágenes así parece indicarlo. La imagen, por así decirlo, vale por sí misma, porque el objeto que se quiere dar a conocer por medio de ella no puede ser imaginado, ni tampoco, hablando con propiedad, ser representado por dicha imagen. ¿Se trata entonces de dar a conocer un sentimiento? Esto será lo que interprete el alumno Lewy, cuando, en un contexto semejante durante la tercera Lección, señale: "Lewy: En este caso usted podría querer decir solo que él expresó una cierta actitud”. Y Wittgenstein le responda: "Yo diría: 'No, no es lo mismo que decir: 'Le tengo mucha simpatía", y puede no ser lo mismo que decir cualquiera otra cosa. Ello dice lo que dice. ¿Por qué usted habría de ser capaz de sustituirlo por cualquier otra cosa?" (1996, p. 148).

Ahora bien, si nos fijamos en la manera como los creyentes suelen utilizar sus enunciados acerca de Dios, no se puede evitar la impresión de que los usan con propósitos descriptivos. Se nos dice, por ejemplo, que Dios es creador del mundo, o que salva a los hombres que creen en Él, o que envió a Jesucristo para salvarnos, etc. Es cierto que tales enunciados son utilizados, como lo dice Crombie, con la clara intención de cometer una transgresión categorial. Pero, precisamente, esa transgresión va en el sentido de realizar un enunciado descriptivo, solo que sobre una realidad que no puede ser descrita de manera directa. ¿Obedece entonces más bien a un sentimiento que desea expresarse, o a una cierta actitud que busca manifestarse, sin encontrar un lenguaje adecuado para hacerlo?

Algunos wittgensteinianos lo han entendido así, siguiendo una línea 
que tiene un gran parentesco con la sustentada por Spinoza en su Tratado teológico-político, donde busca mostrar cómo las enseñanzas de las Sagradas Escrituras, tanto de judíos como de cristianos, no pretenden otra cosa que amonestarnos acerca de nuestra manera de vivir, ofrecernos normas de comportamiento o actitudes ante los avatares de la existencia, pero en ningún momento transmitir una enseñanza doctrinal o un conocimientos objetivo. El título mismo del capítulo XIII del Tratado lo señala con claridad: "Se demuestra que la Escritura no enseña sino cosas muy sencillas, ni busca otra cosa que la obediencia, y que, acerca de la naturaleza divina, tan solo enseña aquello que los hombres pueden imitar practicando cierta forma de vida" (1996, p. 299).

En realidad, como anota Hilary Putnam, "aunque Wittgenstein no dice aquí que el lenguaje religioso sea no cognitivo, porque él 'no desea decir nada que [la persona religiosa] no diría', uno puede, sin embargo, sugerir que, al menos por implicación, él ha dicho que es no cognitivo" (Putnam, 1992, p. 157). Esto, por supuesto, no es aceptable para la teología cristiana. Esta considera que las Sagradas Escrituras tienen un carácter normativo para la utilización del lenguaje que describe las relaciones de Dios con nosotros y de nosotros con Dios. Es cierto que ello no les quita el sentido figurativo a esas expresiones; pero aceptar el carácter de revelación de los textos significa aceptar que su vocabulario expresa de manera correcta lo que Dios ha querido revelar.

\section{c. Tercera lección}

La tercera lección consta de tres partes, que en el texto inglés aparecen claramente separadas por espacios interlineales; espacios que la traducción española no tuvo en cuenta. Después de unas consideraciones preliminares sobre lo que pudiera significar "dejar de existir" y "ser un espíritu desencarnado", el texto hace un largo rodeo acerca de la referencia, buscando precisar la pregunta: ¿en qué sentido decimos que una palabra o un enunciado se refiere a algo?

No voy a detenerme aquí a considerar este importante rodeo, que resulta de gran interés para quienes desean comprender la manera como Wittgenstein examina el problema lingüístico de la referencia. Tomaré solo la consecuencia que del mismo se deriva, en cuanto aplicable a la religión 
como un juego de lenguaje. Para ello seguiré las indicaciones dadas por Hilary Putnam a este respecto.

Ante todo, es bueno señalar que Wittgenstein ha venido mostrando que la idea de lenguajes inconmensurables no resulta adecuada para entender la falta de comprensión entre un creyente y un no creyente. Y tampoco parece ser de mucha ayuda considerar que el lenguaje religioso no es descriptivo o cognitivo. Es muy probable que no lo sea, pero ello no es suficiente para comprender su uso. Ante la objeción que pudiera hacerse, de que los creyentes no consideran que están expresando solo sentimientos o actitudes cuando hablan de sus creencias, Wittgenstein parece querernos decir que tampoco resulta esclarecedor preguntar si el lenguaje religioso posee una referencia. A este respecto habla de confusión, y a ello comenta Putnam:

El uso del lenguaje religioso se asemeja y no se asemeja a los casos ordinarios de referencia: pero preguntar si es "realmente" referencial o "no es realmente" referencial, es caer en confusión. No hay una esencia de referencia. Los pensadores religiosos serán los primeros en decirnos que, cuando se refieren a Dios, su "uso referencial" es bien poco parecido al uso referencial de "mi hermano en América" En pocas palabras, Wittgenstein nos está diciendo cuál no es la manera de entender el lenguaje religioso. La manera para entender el lenguaje religioso no es tratar de aplicarle alguna clasificación metafísica de las posibles formas del discurso. (1992, p. 168).

Entender el lenguaje religioso no es propiamente el resultado de someterlo a un examen gramatical o a un proceso semántico cualquiera, sino que se debe atender a lo que el mismo significa en la vida del creyente, en la manera como orienta su comportamiento. De ahí que la idea de sobrevivencia después de la muerte pueda tener un sentido, que a Wittgenstein le parecía de particular interés, a saber, la idea de que tenemos obligaciones o deberes por los que debemos responder más allá de nuestra existencia temporal. Tal vez no sepamos cómo entender la resurrección, y es posible que el creyente mismo no esté en condiciones de hacérnoslo entender. Utiliza imágenes para ello, pero el valor de esas imágenes no consiste en que con ellas nos dé a conocer una realidad que esté más allá de dichas imágenes. Es como si las imágenes valieran por sí mismas. 
Wittgenstein señala:

Un gran escritor dijo que cuando era niño su padre le había encargado una tarea, y él, de repente, sintió que nada, ni siquiera la muerte, podría librarle de la responsabilidad [de cumplir ese encargo]; era su deber realizarla y ni siquiera la muerte podría hacer que dejara de ser su deber. Dijo que, en cierto sentido, esto era una prueba de la inmortalidad del alma, porque si ésta pervive, la responsabilidad no morirá. La idea viene dada por lo que llamamos prueba. Bueno, si eso es la idea, está bien. (1996, p. 148).

Por su Diario sabemos que esta idea de un juicio después de la muerte tenía para Wittgenstein una particular importancia. Es un aspecto de la religión que parece haberle atraído de manera particular. Juega entonces con una idea, que había sido ya elaborada por J. J. Rousseau, y que había encontrado honda repercusión en el pensamiento de Kant. ¿Por qué los pueblos veneran a sus héroes, que han sufrido y sacrificado sus vidas por los demás?

Oigamos el texto de Wittgenstein, que introduce además un elemento adicional importante:

Como un insecto revolotea en torno a la luz, así lo hago yo en torno al Nuevo Testamento. Ayer se me ocurrió esta idea: si prescindo por completo de pensar en el más allá, / ¿me parece correcto que una persona sufra toda su vida por la justicia, sufra luego quizás una muerte horrible.- y no tenga ningún tipo de premio por esta vida? Admiro a alguien así, lo pongo por encima de mí, y ¿por qué no digo que fue un burro al utilizar así su vida?, ¿por qué no es tonto? O también: ¿por qué no es el "ser humano más desdichado?", ¿no lo será si ahora todo se reduce a que tuvo una vida horrible hasta su final? Pero piensa que yo en estas circunstancias respondiera: "No, no ha sido tonto, porque ahora tras su muerte le va bien". Tampoco esto es satisfactorio. Él no me parece tonto, ciertamente, al contrario, me parece que hace lo correcto. También podría decir: él hace lo justo puesto que recibe el pago justo, y sin embargo ese pago no me lo puedo imaginar como recompensa tras su muerte. "Ese ser humano tiene que volver a casa”, me gustaría decir de una persona así. (2000, pp. 168-170; 15-2-1937). 
La idea no es novedosa, ya que, como he dicho, sobre ella había reflexionado Rousseau para sostener la necesidad de la existencia de un Dios moral, de un Dios que exige la virtud, y que a su vez la premia, así como castiga a quienes obran mal; lo cual conlleva la necesidad de una vida después de la muerte. A este argumento, que retoma Kant en $\mathrm{La}$ religión dentro de límites de la mera razón, Wittgenstein le objeta que para el verdadero creyente la recompensa en la otra vida no puede ser propiamente el motivo de su obrar correcto. De ahí que la imagen del regreso a casa le parezca tal vez más adecuada.

En líneas generales, estos son, a mi parecer, los principales aspectos que pueden destacarse en las tres Lecciones sobre creencia religiosa. Voy a considerar ahora, en forma breve, la controversia que presenta Peter Winch a las tesis de Norman Malcolm acerca del sentido mismo del filosofar wittgensteiniano.

\section{Controversia entre Norman Malcolm y Peter Winch}

Comencemos por contar la historia. Al morir Norman Malcolm, en 1999, tenía casi listo para la publicación un escrito de su particular interés, en el cual comentaba unas palabras de Wittgenstein a su discípulo y amigo M. O’C. Drury. El texto comienza así:

Cuando Wittgenstein estaba trabajando en la última parte de las Investigaciones filosóficas, le dijo a su antiguo estudiante y amigo cercano M. O'C. Drury: "Mi modo de pensar resulta indeseable en los tiempos presentes; debo nadar con fuerza contra la corriente". En la misma conversación dijo: "No soy una persona religiosa, pero no puedo dejar de mirar cada problema desde un punto de vista religioso". (Malcolm, 1993, p. 1).

Ahora bien, cuando los editores quisieron publicar el estudio de Malcolm, lo hallaron demasiado corto como para conformar un libro, y le pidieron entonces a Peter Winch, buen amigo de Malcolm, que lo prologara. Al darse cuenta de que no compartía las tesis centrales del libro, Winch prefirió añadir una discusión al final de la obra. El libro lleva el título de: Wittgenstein. ¿Un punto de vista religioso? 
El interés de la discusión, para nuestro tema, es que la tesis central de Malcolm sostiene que ese "punto de vista religioso", al que hace referencia Wittgenstein, corresponde al modo mismo de su filosofía. En otras palabras, que toda la filosofía de Wittgenstein posee un punto de vista religioso, sin el cual no sería posible comprenderla de manera adecuada.

Tesis como ésta han dado pie para que algunos teólogos o filósofos cristianos hayan creído encontrar en el pensamiento wittgensteiniano un poderoso aliado para sus labores intelectuales. Algunos han llegado a decir, como lo ha hecho hace poco el jesuita y filósofo colombiano Vicente Durán, en un estudio por lo demás muy interesante sobre el lenguaje y la experiencia religiosa: "Wittgenstein es uno de los grandes místicos del siglo XX. Su aporte para una mejor comprensión del lenguaje y de la simbólica religiosa solo puede entenderse desde una concepción profundamente mística de la vida y de la existencia humana" (Durán, 1999, p. 96).

Veremos si tal afirmación es sostenible. Por el momento, voy a exponer brevemente las cuatro tesis con las que sustenta Malcolm su punto de vista, a saber, que entre la visión filosófica de Wittgenstein y la religión existen claras semejanzas o "analogías". Casi todas estas tesis, en lo que respecta a la concepción wittgensteiniana de la filosofía, las habrán visto expuestas y analizadas ampliamente a lo largo del curso. No volveré sobre ello.

1.a Tesis: en la filosofía, el concepto de explicación tiene un límite más allá del cual no es dado avanzar sin caer inevitablemente en confusiones. Otro tanto pasa en la religión: la "voluntad de Dios" pone fin a toda justificación. Parece ser una justificación, pero en realidad no lo es, porque si lo fuera explicaría todo, y entonces no explicaría nada.

2.a Tesis: la actitud de admiración frente a la existencia de los juegos de lenguaje se asemeja a la actitud de admiración que tiene el creyente frente a la existencia misma del universo.

3.a Tesis: la religión expresa la convicción de que en los seres humanos hay algo básicamente erróneo: "Las personas son religiosas -dice Wittgenstein- en la medida en que se creen no tanto imperfectas, sino enfermas" (citado en Malcolm, 1993, p. 87).

A propósito de esta tesis, comenta Malcolm: 
Ahora bien, resulta interesante que Wittgenstein utilice el mismo término de 'dolencia' o 'enfermedad' (Krankheit) cuando se propone caracterizar las maniobras o expedientes a los que acudimos en las teorizaciones filosóficas cuando intentamos dar explicaciones. En el Libro marrón dice: "Hay una especie de enfermedad general del pensamiento que busca siempre (y encuentra) lo que podría llamarse un estado mental a partir del cual brotan todos nuestros actos como de un depósito"' (1993, p. 88).

Esta función terapéutica de la filosofía ha sido muy bien resaltada por Magdalena Holguín en "Wittgenstein: la lógica de la ilusión” (Botero, 2001, pp. 93-109).

4.a Tesis: si bien el cristianismo no es propiamente una doctrina, sino un cambio en la manera de vivir, la filosofía, por su parte, examina los conceptos desde un contexto activo, a partir de nuestras acciones y reacciones prelingüísticas o prerracionales:

Es claro que existe -dice Malcolm- una analogía entre la manera de ver de Wittgenstein, según la cual nuestros conceptos se basan en acciones y reacciones humanas, y su concepción de que lo más fundamental en una vida religiosa no es la afirmación de credos, ni siquiera la plegaria y la adoración, sino más bien ejecutar buenas acciones, ayudar a los demás de manera concreta, tratar sus necesidades como si fueran propias, abrirles el corazón, no ser frío o despectivo con ellos, sino cariñoso. (1993, p. 92).

Peter Winch pasa revista a cada una de estas tesis y presenta argumentos, ya sea para invalidarlas, ya sea para corregirles su significado. No voy a detenerme en cada una de ellas, aunque resultaría, sin duda, de gran interés. Solo voy a recoger los que considero sus argumentos centrales, y con los cuales me parece que sustenta muy bien su interpretación alternativa.

En primer lugar, importa señalar que el texto de Drury no habla de problemas filosóficos, sino de problemas en general, y de ellos dice Wittgenstein que no puede enfrentarlos sino desde un punto de vista religioso. Conviene diferenciar muy bien en Wittgenstein sus reflexiones personales acerca de la religión, sus comentarios y análisis del juego de lenguaje religioso, y su concepción de la filosofía como actividad esclarecedora o terapéutica.

Ahora bien, ¿qué quiere decir "un punto de vista religioso"? Para entenderlo, Winch examina un texto de particular interés, como es la 
carta que Wittgenstein le escribió a su amigo Drury para tranquilizarlo, debido a los escrúpulos que éste le había manifestado por no desempeñar a cabalidad su profesión de médico y por no haberse convertido en un sacerdote católico. Allí Wittgenstein insiste en que la verdadera religión implica un compromiso personal, una voluntad de servir sin esperar recompensa y, sobre todo, considerar todo lo que tenemos o lo que está a nuestra disposición como un don de Dios. Es a estos elementos a los que parece aludir Wittgenstein cuando habla de su manera de confrontar toda clase de problemas. Se trata de algo más impreciso, sin duda, que lo señalado por Malcolm, pero no por ello menos real y más compaginable, por una parte, con lo que nos expresa su Diario y, por la otra, con su repetida insistencia en que él mismo no se consideraba un espíritu religioso. Enfrentar los problemas desde un punto de vista religioso es entonces comprometer en ellos su propia vida, asumirlos como un deber que le ha sido impuesto y ante el cual no hay escapatoria, pero también como un don sobre cuyo ejercicio deberá dar cuenta en alguna forma. Pero esto no tiene por qué significar que su filosofía misma posea un carácter religioso. Más aún, muchas de sus tesis, que en un primer momento parecieron como una oferta inesperada de apoyo a la reflexión de creyentes y teólogos, se han visto, con un poco más de distancia, que comportan elementos de alta peligrosidad para la manera como se concibe la religión dentro de cauces relativamente ortodoxos.

Enrique Romerales, en la presentación que hace del llamado "fideísmo wittgensteiniano", llega a decirnos, en forma, a mi parecer, un tanto excesiva:

Al ver en Wittgenstein a un poderoso aliado contra toda teología -o ateología- filosófica, muchos creyentes han visto un potencial salvador de la religión. Pero si la religión que hay que defender (o apuntalar) es la que tiene en mente Wittgenstein, más vale hundirse con toda dignidad, que mantener a flote un espectro viviente, reconfortándonos diciendo que "esta es la religión más [de]pura[da] y genuina”. (Romerales, 1992, p. 35).

Comparto la tesis de Winch de que la filosofía del vienés no comporta, en sí misma, un carácter religioso o místico. (Por lo demás, esta última palabra resulta muy difícil de precisar). La declaración a Drury debemos entenderla en el sentido de que la manera como él llevaba a cabo sus reflexiones filosóficas lo comprometían de lleno; eran para él, como bien 
lo muestran sus diarios, verdaderos esfuerzos personales en los que se veía comprometida toda su existencia. Wittgenstein fue sin duda un espíritu profundamente religioso. Aunque él mismo no se consideraba como tal, no cabe duda de que tuvo una particular sensibilidad por todo lo que concierne a la religión, y sobre todo en lo que respecta al comportamiento correcto y a la responsabilidad que va más allá de la muerte. Pero esto no permite afirmar que para entender su pensamiento haya necesidad de participar con él en tales sentimientos, comprender y compartir sus inquietudes. Su obra filosófica no se presta para ninguna clase de recuperación religiosa o teológica, porque ella se sostiene por sí misma, con relativa independencia de los sentimientos personales de su autor. Si bien es cierto que para comprender algunos aspectos de su pensamiento pueda ser útil conocer el talante de la persona que los elaboró, creo que hay otros, y muy importantes, que más bien podrían verse oscurecidos si queremos leerlos desde una perspectiva religiosa.

No encuentro mejor manera de poner fin a estas consideraciones sobre Wittgenstein y la religión, que recordar las palabras con las cuales termina su conocida Conferencia sobre ética, dictada hacia 1930, al referirse al sinsentido que muestran las expresiones éticas y religiosas cuando pretenden expresar lo que son valores absolutos:

Después de todo, a lo que nos referimos al decir que una experiencia tiene un valor absoluto es simplemente a un hecho como cualquier otro y todo se reduce a esto: todavía no hemos dado con el análisis lógico correcto de lo que queremos decir con nuestras expresiones religiosas. Siempre que se me echa esto en cara, de repente veo con claridad, como si se tratara de un fogonazo, no solo que ninguna descripción que pueda imaginar sería apta para describir lo que entiendo por valor absoluto, sino que rechazaría ab initio cualquier descripción significativa que alguien pudiera posiblemente sugerir por razón de su significación. Es decir, veo ahora que estas expresiones carentes de sentido no carecían de sentido por no haber hallado aún las expresiones correctas, sino que era su falta de sentido lo que constituía su mismísima esencia. Porque lo único que yo pretendía con ellas era, precisamente, ir más allá del mundo, lo cual es lo mismo que ir más allá del lenguaje significativo. Mi único propósito $-\mathrm{y}$ creo que el de todos aquellos que han tratado alguna vez de escribir o hablar de ética o de religión- es arremeter contra los límites del lenguaje. Este arremeter contra las paredes de la jaula es perfecta y absolutamente desesperanzado. La ética, en la medida en que surge del deseo de decir algo sobre el 
sentido último de la vida, sobre lo absolutamente bueno, lo absolutamente valioso, no puede ser una ciencia. Lo que dice la ética no añade nada, en ningún sentido, a nuestro conocimiento. Pero es un testimonio de una tendencia del espíritu humano que yo personalmente no puedo sino respetar profundamente, y que por nada del mundo ridiculizaría. (1990, p. 43). 